\title{
KŁOPOT Z ISTNIENIEM HENRYKA ELZENBERGA A TRADYCJA POLSKIEJ INTYMISTYKI MODERNISTYCZNEJ (BRZOZOWSKI, KONIŃSKI, KAMIEŃSKA)
}

\author{
KATARZYNA KANTNER*
}

Kłopot $z$ istnieniem to tekst wyjątkowy na tle polskiej intymistyki swoich czasów - to dziennik intymny pisany przez ponad pięćdziesiąt lat przez filozofa, etyka, duchowego mistrza Zbigniewa Herberta. Ta wyjątkowość, zarówno literacka jak i filozoficzna, nie przekreśla jednak możliwości pokazania jego miejsca na tle polskiej autobiografistyki i określenia pewnej specyficznej tradycji, mogącej stanowić dla niego cenny kontekst interpretacyjny.

Małgorzata Czermińska zwróciła uwagę na istnienie w polskiej autobiografistyce duchowej linii opartej na wyraźnych nawiązaniach lekturowych między poszczególnymi intymistami ${ }^{1}$. Choć wnioski badaczki przyjmę jako punkt wyjścia w rozważaniach nad miejscem Kłopotu z istnieniem w polskiej tradycji intymistycznej, pewne modyfikacje wydają się konieczne. Chodzi o koncentrację na utworach, których związek z tekstem Elzenberga jest najbardziej ścisły, które dają okazję do przeprowadzenia ciekawych porównań co do sposobu przetwarzania tej samej tekstowej i filozoficznej tradycji, a wreszcie - bezpośrednio odwołują się do Elzenbergowskiego dziennika. Kłopot $z$ istnieniem skonfrontowany zostanie z Pamiętnikiem Brzozowskiego. Przeanalizuję również, zasygnalizowane już przez Czermińską, paralele między autobiografistyką Elzenberga i Konińskiego². Na osobne miejsce zasługuje Notatnik Anny Kamieńskiej - przykład kontynuacji tradycji Elzenbergowskiej.

Na początku był Brzozowski i to stwierdzenie trudno podważyć. Jak wykazuje Czermińska, czytali go niemal wszyscy - Libert, Elzenberg, Koniński, Trzebiński, Zawieyski i oczywiście Miłosz. Najpełniejszą realizacją formy autobiograficznej jest jego pisany na krótko przed śmiercią Pamiętnik. Dla badaczki jest on jednym ze źródeł do nie napisanej autobiografii autora Płomieni ${ }^{3}$. Czermińska dokonując

\footnotetext{
* Katarzyna Kantner - mgr, doktorantka, Wydział Polonistyki UJ.

${ }^{1}$ Por. M. Czermińska, Autobiograficzny trójkąt: Świadectwo, wyznanie i wyzwanie, Kraków 2000, s. 71-98.

2 M. Czermińska, Autobiografia jako wyzwanie. ( $O$ „Dzienniku” Gombrowicza), „Teksty Drugie" 1994, nr 1, s. 52.

${ }^{3}$ M. Czermińs ka, Autobiograficzny trójkq̨t..., s. 72.
} 
jej swoistej rekonstrukcji, kładzie nacisk na wymiar religijny i interpretuje ją jako „historię nawrócenia” rozgrywającą się w dialogu z pisarstwem Henry'ego Newmana ${ }^{4}$. Nieco inaczej rzecz całą widzi Marta Wyka, która Pamiętnik Brzozowskiego interpretuje w kategoriach pisarskiej autokreacji ${ }^{5}$. Badaczka opierając się na autorskiej przedmowie do Pamiętnika, podważa szczerość intymistycznej narracji, podkreślając fakt, że tekst był w zamyśle autora zespołem wskazówek dla przyszłych biografów. Pamiętnik okazuje się rodzajem świadomej działalności artystycznej, polegającej na wykorzystaniu rozpowszechnionych w modernizmie modeli biograficznych. Zwraca uwagę, że tekst sytuuje się na pograniczu scalającej narracji pamiętnikowej i fragmentarycznej narracji dziennikowej, traktując jednak dzieło Brzozowskiego raczej jako realizację gatunku pamiętnikarskiego. Można jednak, zgodnie z sugestiami Czermińskiej, uwypuklić biegun drugi - dziennikowość. Czermińska podkreśla, że Pamiętnik jest „świadectwem nieustannego, wewnętrznego przekształcania osobowości, obrachunkiem moralnym"6. Aspekt autokreacji jest istotny, sądzić jednak można, że owa sfera „autentyku” również warta jest eksplikacji. W jednej z notatek Brzozowskiego odnajdujemy deklarację:

Zresztą ja już zaprawiam się w szczerości, chcę aby dalsze karty były coraz szczersze, bezwzględniejsze, zarówno jeżeli idzie o moje wnętrze, jak i o innych ludzi ${ }^{7}$.

Mowa tu o „zaprawianiu się w szczerości”, a więc jest ona czymś, co prawdopodobnie dotychczas nie stanowiło dla Brzozowskiego bezwzględnie obowiązującej dyrektywy, ale co właśnie w dziele stanowiącym swoiste resumé powinno dojść do głosu. Nieco dalej pisze Brzozowski:

Z planów moich, które powinienem wykonać [...]. Mogę już dzisiaj pisać tak, żeby to co piszę, wytrzymywało próbę najkulturalniejszej publiczności europejskiej. Dlatego też powinienem mieć odwagę szczerości bezwzględnej. Mówić jasno, gdzie kończy się moje przygotowanie, określać jego granice, królewsko ignorować świat Feldmanów, Garefinów, Garskich i Irzykowskich. Pisać własną terminologią, własnymi stanowiskami, robiąc dla nich miejsce w świecie ${ }^{8}$.

To akt swoistego buntu, zrzucania krytycznych „masek”. Brzozowski obraża w swoich zapiskach niemal wszystkich przyjaciół i kolegów „po piórze” (Irzykowskiego, Nałkowską, Żeromskiego, Berenta), ustawia się w opozycji do współczesnych. Szczerość nie zostaje tutaj sproblematyzowana tak wielowymiarowo, jak w zapiskach Elzenberga, niemniej w obu wypadkach mamy do czynienia z upublicznianiem u schyłku życia pewnych treści, które w ujęciu autora zyskują

\footnotetext{
${ }^{4}$ Ibidem, s. 73-75.

${ }^{5}$ Ref. [za:] M. Wyka, Wstęp [w:] S. Brzozow ski, Pamiętnik, Wrocław 2007.

${ }^{6}$ M. Czermińsk a, Autobiograficzny trójkąt..., s. 73.

7 S. Brzozow ski, Pamiętnik, Warszawa 2000, s. 132.

8 Ibidem, s. 133.
} 
wymiar swoiście buntowniczy. Obaj diaryści sytuowali swoją twórczą biografię w przestrzeni swoistego wykluczenia, w obu wypadkach tożsamość budowana była poprzez przeciwstawienie dominującej atmosferze intelektualnej. Zarówno autor Płomieni jak i toruński filozof akcentowali autobiograficzny wymiar pisarstwa filozoficznego. Inne podobieństwa dotyczą zagadnień podmiotowości, krytyki myśli systemowej i stosunku do języka.

Andrzej Zawadzki rozszerza kategorię autobiograficzności na całość pism Brzozowskiego ${ }^{9}$. Jest ona $\mathrm{z}$ jednej strony narzędziem interpretacji cudzego dyskursu filozoficznego, a z drugiej wpisana zostaje implicite w całość projektu pisarskiego autora Idei. Konsekwencją przełomu modernistycznego okazuje się nie tylko zmiana poglądów w dziedzinie ontologii i epistemologii, ale też wynikająca z nich zmiana koncepcji tekstu filozoficznego - załamuje się wiara w niezależność rzeczywistości względem poznawczej aktywności podmiotu, co wpływa na zbliżenie dyskursu filozoficznego do literatury i zwiększenie wagi modelu autobiograficznego. Widać to wyraźnie we fragmencie Idei cytowanym przez Zawadzkiego:

Tym, co jest zasadnicze, najgłębsze w filozofii, jest przetworzenie życia w świadome dzieło jednostki i nie może być mowy o rezygnacji z filozofii, która nie byłaby jednocześnie rezygnacją ze świadomości [I 209 $]^{10}$.

Brzozowski usiłuje odtworzyć narrację osobistą kryjącą się poza systemami takich filozofów jak Kartezjusz, Leibniz czy Sorel, odczytać je jako zamaskowaną autobiografię ${ }^{11}$. Wyraz podobnych tendencji znaleźć można w przywoływanym przez Zawadzkiego fragmencie Pamiętnika:

[...] wszystkie kosmologie i metafizyki to epizody biografii, to czyjś puls przyspieszony, czyjś błysk oczu [...]. Co nie jest biografią - nie jest w ogóle. Co sobie przypisuje ponadbiograficzne, ponadkonkretnie indywidualne znaczenie, jest właściwie m n i ej rzeczywiste ${ }^{12}$.

Elzenberg podobnie - postrzega wartość dzieła sztuki jako wcieloną w nie „bez żadnej przymieszki wartość esencjalną człowieka"13. Artysta nie wyraża obiektywnej rzeczywistości, lecz ,prawa według których jego świadomość świat po swojemu odbudowuje" (KI 104). Analizując systemy filozoficzne zawsze odnosi je do twórcy, stara się dociec, jaka tendencja moralna kształtowała jego myŚlenie:

${ }^{9}$ Por. A. Zaw ad zk i, Nowoczesna eseistyka filozoficzna w piśmiennictwie polskim pierwszej połowy XX wieku, Kraków 2001, s. 201-205.

${ }^{10}$ Cyt. [za:] Ibidem, s. 202.

11 Ibidem, s. 202-203.

12 S. Brzozowski, op. cit., s. 126.

${ }^{13}$ Wszystkie cytaty podaję [za:] H. Elze n b e rg, Kłopot z istnieniem. Aforyzmy w porzqdku czasu (dalej w tekście jako KI), Kraków 1963. 
Przy tej samej wartości moralnej poglądy dwóch ludzi mogą być różne; i na odwrót: przy dokładnie tej samej treści intelektualnej dwóch filozofii wartość moralną ich twórców - odczytaną z samych tych filozofii! - wypadnie nieraz ocenić jedną jak najlepiej, drugą ujemnie [...] [KI 301].

[...] poglądy filozoficzne, odzwierciedlając istotną część osobowości człowieka, są też wyrazem i jakby intelektualnym symbolem jego natury etycznej. Marny sposób widzenia świata płynie z marnej treści duchowej [KI 345].

W przedmowie do dziennika Elzenberg pisze: ,zamiast na system stawiam na indywidualność” (KI 11). Akt jego publikacji jest ujawnieniem „oblicza” - tego, czego niepełny i zafałszowany obraz mógł być, zdaniem Elzenberga, odczytany z jego nie-dziennikowych publikacji ${ }^{14}$. U Brzozowskiego dziennik-pamiętnik to ostatni etap podszytej autobiograficznością narracji filozoficznej i beletrystycznej. W obu wypadkach jest to etap w którym narracja stricte autobiograficzna urosła wreszcie do rangi pełnoprawnej wypowiedzi filozoficznej.

Brzozowski, podobnie jak autor Kłopotu z istnieniem, przeżywa niepokoje fragmentarysty - napięcie pomiędzy pragnieniem stworzenia filozoficznego opus magnum czy myślowego systemu a konstatowaniem szkicowości własnej pisarskiej praktyki. W Złudzeniach racjonalizmu podważa w ogóle możliwość stworzenia dzieła-syntezy i dokonuje krytyki racjonalizmu rozumianego jako narzucanie na rzeczywistość struktur, które zafałszowują jej dynamikę:

co daje się powiedzieć w sposób całkiem logiczny i przekonywający, jest już martwe. Żaden logiczny zakończony systemat „nie da” się urzeczywistnić, dlatego właśnie, że jest już urzeczywistniony $[\mathrm{I} 431]^{15}$.

Przychodzi tu na myśl to, co u Elzenberga nazwane zostać może ,apologią fragmentaryczności”, czyli zespół poglądów, w myśl których to co logiczne i w pełni racjonalne, skończone i wyjaśnione jest martwe, bo właśnie „między postawieniem problemu” a jego rozwiązaniem, coś , «dochodzi do bytu», «wkracza w istnienie», ma miejsce «kontakt z rzeczywistością»" (KI 329).

Język staje się dla Brzozowskiego nie tyle przeźroczystym medium, co czynnikiem aktywnie kształtującym odbiór rzeczywistości ${ }^{16}$. Ścierają się tu ze sobą dwie tendencje - z jednej strony, kontynuując tradycję Nietzscheańską, polski myśliciel traktuje filozofię jako rodzaj twórczości literackiej, z drugiej strony zaś, idąc za Bergsonem, pragnie stworzyć nowy język filozoficzny, dezautomatyzujący percepcję i przystosowany do oddania filozoficznych problemów nowoczesności ${ }^{17}$. Zawadzki podkreśla, że Brzozowski metaforami posługiwał się konsekwentnie jako środkiem wyrazu nowatorskich idei filozoficznych. Jedną

\footnotetext{
${ }^{14}$ H. Elzen berg, Z dzienników 1941-1960, „Znak” 1961, nr 81, s. 302.

${ }^{15}$ Cyt. [za:] A. Zaw ad zki, op. cit., s. 211.

16 A. Zawadzki, op. cit., s. 220.

17 Ibidem.
} 
z nich jest metafora sieci, która ma oddać „dynamiczny i aktywny oraz jednocześnie konwencjonalny charakter poznania kategoryzującego i porządkującego amorficzną rzeczywistość"18. Bardzo podobne poglądy wyrażał Elzenberg, który również stosował metaforę języka-sieci:

Język złym punktem wyjścia. Rzeczywistość składa się z treści indywidualnych; treści indywidualne nie mają odpowiedników w słownictwie; słownictwo jest zbiorem znaków dla pojęć; pojęcia to tylko sieć kratek narzuconych na rzeczywistość. Dlatego między innymi zaufanie do języka to zły punkt wyjścia dla poznania rzeczywistości [KI 271].

Obaj filozofowie stają się rzecznikami ekspresji tego, co konkretne i indywidualne, tworzą projekt języka opozycyjny względem agresywnego racjonalizmu. Jest to jeden z najistotniejszych problemów filozofii Elzenberga, szeroko sproblematyzowany w Kłopocie z istnieniem. Filozof opiera swój projekt na metaforze, porównaniu i myśleniu obrazowym, które o wiele lepiej nadają się do dyskursywnego przybliżania rzeczywistości ${ }^{19}$.

Brzozowski i Elzenberg byli czytelnikami Amiela i, podobnie jak on, wyłamywali się z tradycji Kartezjańskiej. Andrzej Zawadzki opisuje ewolucję, jaka zaszła w myśleniu Brzozowskiego o podmiocie ${ }^{20}$. Pierwotną inspiracją był dla niego empiriokrytycyzm Macha i Avenariusa, w myśl którego za podstawowy błąd dotychczasowej filozofii należy uznać ścisłe rozdzielenia sfery podmiotowej i przedmiotowej. Podmiot i przedmiot okazują się metafizycznymi konstruktami pozbawionymi substancjalności - są tylko wiązką wrażeń i impresji. Dla Brzozowskiego filozofia ta stanowiła punkt wyjścia, wkrótce jednak, pod wpływem Bergsonowskiej krytyki empiriokrytycyzm stworzył koncepcję ,ja” głębokiego, złożonego z trzech warstw. Pierwsza z nich to sfera świadomości i jej wytworów, która jednak wymaga interpretacji hermeneutycznej celem dotarcia do warstwy drugiej: sfery instynktów i popędów, ale też tego co indywidualne i konkretne. Pod tymi dwoma warstwami znajduje się ,ja” pojęte jako wytwór procesów społecznych i historycznych. Brzozowski wysuwa postulat swoistej hermeneutyki jaźni powierzchniowej, która miałaby na celu dotarcie do owych głębszych, ukrytych warstw, a sama świadomość określona zostaje metaforą „dokumentu pisanego kluczem".

U Elzenberga również daje się zauważyć wyraźne wpływy empiriokrytycyzmu, który jednak stara się on przezwyciężyć, by ocalić podmiot w znaczeniu osoby etycznej ${ }^{21}$. Autor Kłopotu z istnieniem również wypracowuje model „ja” trójwarstwowego. Zawadzki zwraca uwagę na istnienie dwóch poziomów

${ }^{18}$ Ibidem, s. 221.

${ }^{19}$ Por. H. Elzen berg, O funkcji komunikatywno-poznawczej wysławiania się obrazowego [w:] t e go ż, Wartości i człowiek, Toruń 1966.

${ }^{20}$ Ref. [za:] A. Zaw a z z i, Dokument pisany kluczem, ,Teksty Drugie” 2002, nr 4, s. 68-80.

${ }^{21}$ Por. A. Zaw ad zki, Nowoczesna eseistyka..., s. 134. 
Elzenbergowskiego podmiotu: pierwsza to świadomość, ,«ja» zjawiskowe, relacyjne, przygodne, możliwe do pojęciowego uchwycenia", druga to głębsza sfera nieuświadomionych instynktów. Znamienne, że, podobnie jak u Brzozowskiego, to właśnie owo uwarunkowane biologicznie ,ja” głębokie jest nośnikiem indywidualności:

Twierdziłem kiedyś: tzw. siła indywidualności ma źródło w sile nieuświadomionych instynktów, które człowieka ponoszą. Można to uzasadnić tak oto: co nieświadome, to nie podlega dyskusji; czynów, które płyną z nieświadomości jednostka po prostu nie może sobie w y ob raz ić innymi. Więc też ich przed sobą nie uzasadnia, a to jest zysk, a nie strata: nic nie zachwiewa jednolitości i pewności siebie w działaniu [KI 109].

Na tym etapie refleksji zasadnicza niemożność jakiejkolwiek ingerencji w ,ja głębokie" wynika z jego zasadniczej poznawczej niedostępności. Z czasem jednak Elzenberg łagodzi swoje stanowisko: owo ,ja” jest czynnikiem dynamizującym i źródłem podmiotowej energii, ale podlega etycznemu kształtowaniu, które urasta do rangi najwyższego życiowego zadania:

Natomiast tak nasze czyny, jak nasze myśli i stany uczuciowe, wyrastają z korzenia wspólnego, jakim są pożądania, pragnienia, dążenia, impulsy. Tu dopiero jest właściwe centrum, tu dopiero jestem właściwy ,ja”, i tego to „siebie” muszę doskonalić, jeśli chcę, by czy to moje czyny były coś warte, czy to by moje myśli i stany uczuciowe zachowały swą czystość [KI 264].

Ale jest jeszcze sfera trzecia, najgłębsza - fundamenty podmiotowości. To zasadnicza różnica pomiędzy dwiema omawianymi koncepcjami. O ile, jak chciał Zawadzki, u Brzozowskiego sferę trzecią współtworzą oddziałujące na ,ja” ponadindywidualne procesy dziejowe i społeczne, o tyle w myśleniu Elzenberga najbardziej charakterystyczna jest właśnie aspołeczność poziomu trzeciego. Znamienny jest tutaj cytat z 3 I 1944:

„Po długim wdrążaniu się w pojęcie jaźni samą tylko metodą poetów i mistyków, przez obserwację wewnętrzną, przez piaski nie stawiające oporu zstąpiłem dalej, aż wreszcie na dnie jako fundament znalazłem zbiorowość" (Barrès). W tym sęk: tu jest punkt, gdzie się drogi rozchodzą. Ja tu jestem po stronie Bergsona, który w konsystencji pochodzącej od społeczeństwa widzi konsystencję liści i łodyg splątanych na powierzchni stawu; zakorzenienie jednak, to co innego; z dna każda poszczególna jednostka wyrasta sama [KI 314].

Owo „dno” jest więc wspólne i nie uwarunkowane społecznie. Może być ono utożsamiane z dostępną w doświadczeniu mistycznym dziedziną „Nieokreślonego”, czy też „Bytu”. Elzenberg stara się postrzegać podmiotowość w oderwaniu od wielkich procesów dziejowych. Widać to wyraźnie, kiedy ustanawia swój prywatny kanon poezji dwudziestolecia międzywojennego:

Jako krytyk, czy historyk literatury musiałbym o tym wszystkim mówić inaczej; ale teraz mówię jako ja (,Ja, Miguel de Unamuno”), der Einzige: pozadziejowy, własnym prawem stojący i własne prawa dyktujący ,podmiot sam w sobie” [KI 306]. 
To w sferze tego co indywidualne realizują się wartości takie jak „mądrość, świętość, wolność, zbawienie” (KI 248). Elzenberg przeciwstawia tutaj „Małe Dzieje, te kapliczkowe”, temu co nazywa „Dziejami Wielkimi” - ta dziedzina „,wielkich formacji” niesłusznie urasta do rangi nośnika istotnego sensu (KI 249). Owa różnica podejścia najpełniej uwidacznia się w stosunku do religii. Elzenberg był rzecznikiem religijności wysoce indywidualistycznej i nieco eklektycznej. Jego stosunek do chrześcijaństwa jest krytyczny:

Chrystianizm, ten zorganizowany, masowy, ten, który był i jest siłą społeczną, to po prostu organizacja Wielkiego Odczepnego dla Absolutu [...]. I czy, biorąc religie w tym sensie i przeciwstawiając je mistycyzmom, nie należy powiedzieć ogólnie: Religie, to organizacja odczepnego dla Absolutu? (KI 344).

Katolicyzm, jak na moje potrzeby, za dużo rzeczy na ziemi potwierdza i sankcjonuje. Jest to uroczysty „strop uświęcenia”, nieco zbyt równomiernie sklepiony, nad ascezą i nad zmysłami, nad krzywdzonym i tym, który krzywdzi, nad wyrzeczeniem i wszelką arcy-ludzką, arcy-ziemską świętością i cielesnością, panowaniem i mocą. Religia godna tej nazwy niesie ze sobą więcej miecza, więcej zaprzeczeń [KI 376].

Katolicyzm wikła się w świeckość, jest rodzajem duchowego konformizmu. Zupełnie inaczej ocenia go Brzozowski. W Legendzie Młodej Polski odżegnywał się on od tego, co nazywał katolicyzmem „Polski zdziecinniałej”"22. Zdaniem filozofa istnieje jednak także katolicyzm w formie czystej i dojrzałej, który zostaje scharakteryzowany jako najdonioślejsza z dotychczasowych formacji kulturowych, będąca kontynuacją tradycji grecko-rzymskiej ${ }^{23}$ :

By dojść do jakiejkolwiek łączności z Bytem, jednostka musi wżyć się w ludzkość, jako konstrukcję, jako formę, mającą w sobie więcej niż cokolwiek innego w świecie z archetypu, formy bezwzględnej. Spencer, buddyzm Lafcadia Hearena etc., etc., wszystko to są usiłowania znalezienia prawdy na drodze niezależnej od udziału w konstruktywnym życiu ludzkości. Dlatego też pozornie tylko istnieje rzeczywistość w tych systemach, rdzenny nihilizm założeń musi przemóc ${ }^{24}$.

Dla Brzozowskiego, wskutek braku zadomowienia we wszechświecie, człowiek musi wypracować oswojoną przestrzeń w wrogim uniwersum, nie robi tego jednak sam. Andrzej Mencwel pisze o pewnym podmiocie zbiorowym „,zorganizowanym społecznie, uformowanym psychicznie”25. Świat kultury to świat „więzi międzyludzkich, zasad współżycia, praw moralnych", a jednostka ma za zadanie współtworzyć własnym wysiłkiem wielką budowlę kultury, której najpełniejszą realizacją jest właśnie katolicyzm ${ }^{26}$. Jest to projekt kultury jak wspólnie wzno-

${ }^{22}$ Por. A. Mencwel, Obecność w prawach i celach [w:] S. B rzozow s ki, Pamiętnik, Warszawa 2002, s. 20.

${ }^{23}$ S. B rzozowski, op. cit., s. 88.

${ }^{24}$ Ibidem.

${ }^{25}$ A. Mencwe1, op. cit., s. 20.

${ }^{26}$ Ibidem, s. 20-21. 
szonego gmachu, w którym każda jednostka ma swój udział i który na nią z kolei wtórnie oddziałuje. Dla kontrastu warto tu zacytować pogląd Elzenberga:

W ostatecznej instancji nie chodzi o wielkie formacje, nie chodzi o instytucje, ojczyzny, religie, prądy duchowe [...] Jeśli im do tego imperium rzymskie albo katolicyzm mogą dopomóc, to cześć im! chwalmy katolicyzm i jego wskazania. Ale nigdy nie zapominajmy, że rola ich jest tylko służebna wobec konkretnych dusz ludzkich i konkretnych, przez te dusze tak czy inaczej realizowanych wartości [...]. W konkretnych osiągnięciach konkretnych istot urzeczywistnia się sens istnienia; dzieje są tylko kanwą, ramą, ustawieniem perspektyw, podłożem [KI 249-250].

Mimo wątpliwości co do możliwości funkcjonowania poza strukturami dziejowymi i społecznymi, Elzenberg prezentował jednak nastawienie deprecjonujące zbiorowość - twórcza aktywność jednostki jest autoteliczna i domaga się obrony. Może dlatego w jednym z fragmentów dziennika tak oto opisuje różnicę między sobą a autorem Legendy Młodej Polski:

Dla mnie szczytem piramidy jest dzieło sztuki: dopiero ona potrafi wydobyć kwintesencję piękności z wszelkiego poczynania ludzkiego. U Brzozowskiego natomiast dzieło sztuki ma się przyczyniać do wytworzenia warunków - warunków w psychice ludzkiej, z których by się mógł zrodzić czyn bohaterski. Też dobrze! to tylko smutne, że nie uwzględnia artyzmu jako artyzmu. Brzozowski (sam to powiada) ,nie ma czasu”, tak jak Słowacki nie miał czasu na „ludzkie zabawki”. Brzozowski nie widzi, że dla artysty dzieło sztuki jest tym, czym dla człowieka czynu jest czyn bohaterski: bohaterstwem artysty jest artyzm [KI 69].

Elzenberg zarzuca Brzozowskiemu „odzieranie artystów z ich artyzmu” w imię apoteozy fałszywie pojętego czynu; postawie tej przeciwstawia hasło: „sztuka dla sztuki”. Wskazuje to na zasadniczy rys jego myślenia: przyznawanie prymatu nie podporządkowanej celom zewnętrznym indywidualnej realizacji wartości. To bardzo typowe dla Elzenberga - to co jednostkowe filozof zwykle wynosił ponad zbiorowość. „Społeczeństwo może w swej masie zawierać ludzi mądrych i dobrych: samo zawsze jest głupie i złe"27. Sądził, że niepodobna realizować w nim tego, co najważniejsze - obiektywnie istniejących wartości, które są tym, co nadaje życiu człowieka rzeczywisty sens. „W świecie wartości jest się

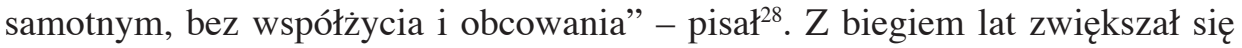
jego sceptycyzm względem wielkich formacji społeczno-kulturowych - odrzucił ideę państwa, dzieje uznał za bezsensowne. W ogólnym obrachunku konstatował zasadniczą sprzeczność między wymogami swojej aksjologii a życiem wspólnotowym, wybierając izolację i swoisty arystokratyzm ducha.

Tworzony przez niespełna dwa lata Pamiętnik Brzozowskiego nie zdążył rozrosnąć się do rozmiarów summy duchowego rozwoju jednostki. Stąd może ujęcia

${ }^{27}$ H. Elze n be rg, Sprawy zbiorowości ludzkiej a mój system myślowy [w:] t e g o ż, Z filozofii kultury, Kraków 1991, s. 357.

${ }^{28}$ Ibidem, s. 361. 
retrospektywne, próby ukazania genezy własnej formacji duchowej, nawroty do dzieciństwa - wszystko to, co wprowadza elementy narracji pamiętnikarskiej, scalającej. Brzozowski wiedział, że musi się spieszyć, bo „Śmierć może czekać lata, ale potencjalnie, in idea, stoi za ramieniem" 29 . Nie dany był mu ten czas, który dla Elzenberga był czynnikiem pozwalającym na pełną eksplikację podmiotowych treści, bo przecież ,nie można do wszystkiego w sobie dobrać się naraz i musi być jakaś kolejność” (KI 461). Wspólnym mianownikiem obu tekstów jest z pewnością ich parergiczność - są zapisami pomysłów i intuicji, które w wypadku Elzenberga miały często szansę rozrosnąć się w większe formy, a dla Brzozowskiego stanowiły rodzaj gorączkowego depozytu podyktowanego chęcią ocalenia tego, co jeszcze ocalić można.

W przypadku pisarstwa Konińskiego trudno mówić o bezpośrednich zależnościach intertekstualnych z dziennikiem Elzenberga, istnieje jednak wiele powodów dla których wypada przyjrzeć się ewentualnym powinowactwom - to przykłady postawy introspektywnej, skoncentrowanej na zasadniczych pytaniach filozoficznych i religijnych. Obaj autorzy wyrastają z tej samej formacji intelektualnej, momentu historycznego (Koniński jest od Elzenberga młodszy o zaledwie cztery lata), co ujawnia się nie tylko w zakresie podobieństwa lektur (Brzozowski, Augustyn, Marek Aureliusz, Pascal, Bergson, Nietzsche), ale przede wszystkim w podobnym stosunku go języka i myślenia zlogicyzowanego. Można powiedzieć, że teksty Konińskiego i Elzenberga to dwie kontynuacje linii intymistyki modernistycznej, za której pierwszy element uznać można tekst Brzozowskiego. Zauważył to Maciej Michalski, który podkreśla ogromny wpływ, jaki Pamiętnik wywarł na autobiograficzne zapiski Elzenberga i Konińskieg, zarówno w warstwie formalnej, jak i ideowej.

Adam Fitas zwraca uwagę na gradację w obrębie dialektyki świadectwa i wyznania jaka zachodzi w intymistyce Konińskiego: od Wojny, poprzez Uwagi aż do Ex labiryntho i Nox atra następuje intensyfikacja refleksji filozoficzno-religijnej i żywiołu introspekcyjnego, przy jednoczesnym umniejszaniu roli faktogra$\mathrm{fii}^{30}$. Formalnie najbliższym tekstowi Elzenberga są Uwagi-powstający w latach 1941-1943 dziennik intymny, w którym sfera świadectwa, choć nadal obecna, ustępuje wobec intensyfikacji introspektywnej refleksji filozoficzno-religijnej. Fitas lokuje dziennik w tradycji autobiografistyki duchowej korzeniami sięgającej Wyznań świętego Augustyna, a z drugiej strony umieszcza w kontekście polskiej diarystyki wojennej i w obu wypadkach jako tekstową egzemplifikację wymienia Kłopot z istnieniem $^{31}$.

Koniński podzielał marzenie o systemie. Zauważa to Fitas, który, analizując Ex labiryntho, podkreśla obecną w tekście dążność do ujęcia zagadnień religij-

${ }^{29}$ S. B rzozowski, op. cit., s. 41.

${ }^{30}$ Por. A. Fitas, Głos z labiryntu. O pismach Karola Ludwika Konińskiego, Wrocław 2003, s. 77-78.

${ }^{31}$ Por. ibidem, s. 224-228. 
nych $w$ formie racjonalnych, logicznie uporządkowanych rozważań ${ }^{32}$. Warto tu przytoczyć jeden z fragmentów pism Konińskiego:

[...] teologia jest działem metafizyki, a metafizyka nie różni się jako praca umysłowa od żadnej innej pracy umysłowej, nawet nie od matematyki. Są przyjęte pewniki, teraz robi się konsekwentny system twierdzeń. Czy system ten jest rzeczywiście konsekwentny, to właśnie kwestia czysto dyskursywna, czysto techniczna [Ex 53] $]^{33}$.

Tekst Ex labiryntho rozpada się jednak na zbiór ujęć fragmentarycznych, w których po wielokroć powracają te same problemy, rozpatrywane na szereg różnych sposobów, co skłania Fitasa do podkreślania „dialektyki ścisłości i niejasności, pewności i niepokoju, ładu i nieporządku"34. Obok tendencji do nadawania rozważaniom formy możliwie zbliżonej do sylogizmu, spotykamy w tekście Konińskiego fragmenty odpowiadające poetyce gnomy czy aforyzmu; język pojęć abstrakcyjnych co jakiś czas inkrustowany jest opisami konkretnych przeżyć, anegdot, wspomnień, mającymi jednak zawsze przełożenie na sferę rozważań filozoficznych ${ }^{35}$. Ewokowaniu konkretu służy stosowanie pojęć wieloznacznych, metafor, porównań; w tok wypowiedzi wplecione zostają cytaty z literatury pięknej ${ }^{36}$. Łączy się z tym pogląd Konińskiego na poznawczą funkcję języka:

„Rzeczywiste” poznanie rzeczy tylko przez czucia; o czym teoria mówi skrótami abstrakcyjnymi, o tym poezja mówi konkretnie, czuciem do czucia; język poezji, tak nieokreślony, jest w istocie ściślejszy gdy idzie o sprawy metafizyczne i mistyczne niż silący się na precyzję język spekulacji metafizyczno-teologicznej: sugeruje symbolicznie coś rzeczywistego, co się wymyka abstrakcji [...] [Ex 152].

W Ex labiryntho zarysowuje się również opozycja pomiędzy dwoma sposobami autoprezentacji podmiotu: dominuje wprawdzie tendencja do depersonalizacji na wzór podmiotu naukowej rozprawy, ale dostrzegalne są również pęknięcia w postaci osobistych wyznań, wspomnień z obszaru indywidualnej biografii ${ }^{37}$. Tendencje zbliżające zapiski Konińskiego do obszaru autobiografistyki i literatury pięknej ulegają intensyfikacji w tomie Nox atra - mamy tu wciąż do czynienia z tematyką filozoficzną, o której jednak mówi się językiem obrazowym ${ }^{38}$. Co znamienne, zarówno dla Elzenberga jak i dla Konińskiego sfera określana mianem Absolutu stanowi punkt, w którym załamują się możliwości racjonalnego dyskursu:

\footnotetext{
32 Por. ibidem, s. 71-93.

33 Cyt. [za:] Ibidem, s. 80-81.

${ }^{34}$ Ibidem, s. 91.

${ }^{35}$ Por. ibidem, s. 93-94.

36 Por. ibidem, s. 95.

37 Por. ibidem, s. 100-101.

${ }^{38}$ Por. ibidem, s. 105-106.
} 
[...] Bóg sam w sobie, wiekuisty, niepojęty dla umysłu, niepochwytny w sieć pojęć intelektualnych, które zawsze jednostronnymi są tylko aspektami rzeczy. O Nim cokolwiek powiesz, że jest albo nie jest wszechmocny, że jest albo nie jest osobisty, że jest albo nie jest przyczyną świata itp., zawsze będziesz poniżej jego własnej, nieograniczonej rzeczywistości [Nox 305] $]^{39}$.

\section{Na podobną refleksję napotykamy w Uwagach:}

Czar Absolutu: w Absolucie wszystkie sprzeczności się godzą, absurdy stają się prawdami; kto raz przyjmie, że jest taka rzeczywistość, która sobie z logiki naszej dyskursywnej drwi, temu już wolno wierzyć we wszystko, co mu się żywnie podoba. Ale zarazem postulat Absolutu, jako koincydencji oppositorum jest postulatem logiki miłości ${ }^{40}$.

W pierwszym z przytoczonych fragmentów znów odnajdujemy metaforę języka-sieci. Poznawcza wartość ewokowanego przez nią dyskursu stricte racjonalnego jest waloryzowana negatywnie poprzez swoją nadmierną ogólność, „jednostronność”. Okazuje się środkiem, za pomocą którego niepodobna oddać zarówno tego co przez swoją indywidualność i konkretność umyka abstrakcyjności jego pojęć, jak i rzeczywistości wyższej - osobowego Boga Konińskiego, mistycznego Absolutu Elzenberga. Stąd w twórczości Konińskiego intensyfikacja obrazowych form wyrazu z pogranicza języka poetyckiego, stąd Elzenbergowskie podkreślanie poznawczej funkcji wypowiedzi metaforycznej, języka apofatyki, tego co nazywa „pojęciami płynnymi” (KI 331). Dobrą egzemplifikację specyficznego dla obu diarystów zwątpienia w ekspresyjną moc języka znajdujemy w Uwagach:

Tylko konkret jest prawdziwy, tylko konkret, szczegół, fragment przeraża, boli; wszystkie wyrażenia ogólne, abstrakcje są blade i kłamią; wszystkie nazwy kłamią, wszelkie wyrażanie się kłamie. Język okłamuje rzeczywistość, forma jest zdrajczynią treści; wyrażając się odrzucamy od siebie to, co jest w treści najdolegliwsze; najrzeczywistsze; a wyrażeniami ogólnymi, abstrakcjami tak się spoufalamy ze strasznymi treściami, tak je obłaskawiamy $[\ldots]^{41}$.

Tak jak w wypadku Elzenberga język pojęć okazuje się „złym punktem wyjścia”. Specyfika Konińskiego polega na tym, że kładzie on nacisk na aspekt cierpienia, które nie oddaje się racjonalizacji, a chłodny język filozoficznych abstraktów okazuje się „,zdradą” wobec rzeczywistości. Logice tradycyjnej przeciwstawiona zostaje związana z rzeczywistością boską „logika miłości”, w której dojść ma do zniesienia przeciwieństw i paradoksów. Koniński w swoich pismach zmaga się z zagadnieniem teodycei, ale na każdym kroku napotyka na aporie, makabryczną rzeczywistość. Ma też silne przeświadczenie, że każdy system jest tylko jednym z możliwych sposobów patrzenia:

\footnotetext{
${ }^{39}$ Cyt. [za:] Ibidem, s. 115.

40 K. L. Koniń ski, Uwagi, Poznań 1987, s. 153.

${ }^{41}$ K. L. Konińs ki, Uwagi, Poznań 1987, s. 84-85.
} 
Wygrać w końcu logikę jednostronnego aspektu rzeczywistości, dążyć do systemu choć wiadomo, że każdy system pomija część rzeczywistości; ale tylko system daje uspokojenie logiczne i tylko system ma w sobie siłę akcentu, która potrafi brać inne umysły. Mieć system i mieć sceptycyzm względem tego systemu. Eklektyzm nie ma wyrazu? Choć, kto wie, może jest punkt absolutny, z którego się ukazują wszystkie systemy [...] $?^{42}$

Koniński ukazuje daremność dążenia do ogarnięcia całości - ta jest domeną Boga; myśl ludzka skazana jest na nieustanne dążenie, wikłanie się w paradoksy, a myśliciel powinien pogodzić się z kondycją fragmentarysty. Na krótko przed śmiercią Koniński notuje w swoim dzienniku:

Zrezygnuj z chęci widzenia wszystkiego, wytłumaczenia, zracjonalizowania, uklasyfikowania wszystkiego [...] nie trap się tym, nie próbuj kleić zwartego logicznie światopoglądu; wszystko zostaw w szczegółach, w częśsiach $[\ldots]^{43}$.

Fitas dostrzega aspekt myślenia antysystemowego: „,Diariusz nie zmuszał do prób systemowego ogarnięcia własnej świadomości, które zazwyczaj dla myślicieli diarystów nie jest w ich hic et nunc osiągalne czy nawet potrzebne" Badacz przytacza następujący fragment Kłopotu z istnieniem, który doskonale koresponduje z przywołanym powyżej fragmentem Uwag:

Dawniej miałem tę ambicję, żeby myśl swoją zamknąć w jakiejś ostatecznej formule, ująć ją w szereg prawd, których mógłbym się trzymać. Za braki dyskwalifikujące, zabójcze, uważałem niezgodność dwóch wypowiedzi i tak samo aproksymatywność myśli, albo jej płynność. Dziś wiem, że każda wypowiedź unaocznia tylko pewien aspekt mej myśli, mieniącej się, wielocieniowej, wijącej się jak strumień poprzez sprzeczności, i która tylko poprzez sprzeczności, w ciągłych przybliżeniach, przemianach i w ciągłym ruchu zdoła ujawnić treść swoją istotną, nie dającą się zamknąć w formuły [KI 228].

Bardzo dokładnie analizuje te zagadnienia Maciej Michalski, który zestawia intymistykę Elzenberga, Brzozowskiego i Konińskiego, analizując obecne w niej formy wyrazu treści filozoficznych. Osobne miejsce poświęca aforyzmowi, roli cytatu, elementom dyskursu naukowego, modlitwie, metaforze, exemplum czy kształtowanym przez autorów elementom świata przedstawionego. Każdy z tych środków traktuje jako wyraz specyficznego dla tych pism napięcia między naukowością a literackością, myśleniem systemowym a dążeniem do oddania tych aspektów rzeczywistości, które mu się wymykają. Na przykładzie przywołanych tutaj tekstów oraz Podróży do piekiet Micińskiego badacz omawia jedną z trzech (obok apokryfu i paraboli) wyróżnionych przez siebie strategii filozofowania w polskiej prozie współczesnej-dyskurs ${ }^{45}$. W ujęciu Michalskiego jest ona opo-

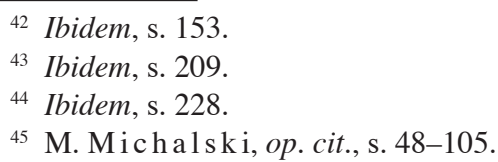


zycyjna względem literatury poprzez swoją niefikcjonalność i ograniczenie roli elementów obrazowych. Od dyskursu naukowego odróżnia ją z kolei osłabienie asercji uzyskiwane głównie poprzez zwiększenie roli perswazyjności i zastosowanie środków typowych dla praktyki literackiej oraz odejście od rygorów logicznego rozumowania i odpowiadającego mu uporządkowania wypowiedzi. Istotą tej formy wyrażania treści filozoficznych jest jednak dla Michalskiego podmiotowość piszącego. To ona w głównej mierze determinuje jej kształt, bo dążąc do maksymalnej bezpośredniości wyrazu omija i przełamuje konwencje komunikacyjne i literackie ${ }^{46}$.

Intymistyka Konińskiego to kolejny, obok Pamiętnika Brzozwskiego, przykład pisarstwa z pogranicza dwóch dyskursów, w którym owa pograniczność zostaje explicite sproblematyzowana i wynika z określonych poglądów filozoficznych piszącego. Jako bezpośredni kontekst dla Kłopotu z istnieniem uznać należy Uwagi - przykład dziennika intymnego, w którym jednak nie zyskał istotnego znaczenia, problem podmiotowości. Brak mu też autorskiego gestu wyboru, który wpłynął na formę Kłopotu z istnieniem. Istotna jest także różnica rozpiętości czasowej - w wypadku tekstu Elzenberga, powstającego przez pół wieku, mówić można o dzienniku ,dojrzewającym” wraz ze swoim autorem. Uwagi to, podobnie jak tekst Brzozowskiego, rodzaj zalążka, który z przyczyn obiektywnych, nie miał szans rozwinąć się w tekst o walorach specyficznie pojętej całościowości.

$\mathrm{Na}$ tle przywołanych dotychczas dzienników wyróżnia się Notatnik Anny Kamieńskiej. Jest to dziennik poetki, nie filozofa; rzadko daje się tutaj zauważyć tendencję do obiektywizacji czy systematyzacji refleksji; dziennik jest w dużej mierze zapisem indywidualnych emocji i przeżyć, silnie zakorzenionych w biografii autorki. Jego przywołanie wydaje się niezbędne z kilku powodów: 1) stanowi jedno z pierwszych świadectw odbioru Kłopotu z istnieniem ${ }^{47}$; 2) w swojej poetyce - aforystyczności, fragmentaryczności, operowaniu cytatem - zbliża się wyraźnie do tekstu Kłopotu z istnieniem czy intymistyki Konińskiego; 3) mamy tu po raz kolejny do czynienia z tekstem stojącym na pograniczu pewnych dyskursów, tyle że pisanym niejako „od drugiej strony” - tym razem to poeta sięga po język filozofii; 4) Kamieńska problematyzuje swój stosunek do języka i systemu, dochodząc w wielu aspektach do wniosków zbieżnych z przemyśleniami Brzozowskiego, Konińskiego i Elzenberga.

Diarystka wspomina o lekturze Elzenberga w przedmowie do swojego tekstu: „Być mężnym wobec bytu - jak mówi profesor Elzenberg - oto sens tego mozolnego zapisu"48. Inny zapis aktu lektury pochodzi z kwietnia 1972:

Elzenberg (Kłopot $z$ istnieniem) o wierze każdego dnia zdobywanej na nowo. Elzenberg pisze, że przeciwnicy nam pomagają, pomagają nam fortyfikować się, wyodrębniać, określać nasze

\footnotetext{
46 Ibidem, s. 53-54.

47 Por. M. Czermińs k a, Autobiograficzny trójkq̨t..., s. 93.

48 A. Ka mień s ka, Notatnik 1965-1972, Poznań 1982, s. 7.
} 
postawy. To może być płaszczyzna tej najtrudniejszej miłości ewangelicznej, miłowania nieprzyjaciół.

Moje grzebanie w książkach - to próby szukania ratunku u wielkich nieznanych przyjaciół, współ-czujących, jeśli czuli i cierpieli podobnie. Wiele pociechy jest w heroicznej postawie Elzenberga. Pociecha przecież to nie słowa litości, ale przykład mężnego cierpienia, mężnego myślenia i życia, mężnego znoszenia czasu. Elzenberg o roli mistyki: „Mistyka jest organizacją samotności jednostki" ${ }^{49}$.

Powyższe twierdzenie koresponduje z jedną z notatek Elzenberga:

O książkach. Czym dla powierzchownych dusz są zetknięcia z ludźmi na co dzień, tym dla głębszych jest książka, lektura. Książki nie trzeba zbyt jednostronnie traktować jako „dzieła”, „utworu”; należy pamiętać, że jest to także „okólnik od nieznanych przyjaciół” [KI 196].

Te nawiązania intertekstualne zaświadczają obecność podobnego stylu lektury. Czermińska pisząc o Notatniku, konstatuje, że posiada on cechy antologii cytatów i że pod względem ich ilości przewyższa wszystkie znane jej polskie dzienniki $^{50}$. Notatnik okazuje się zapisem utożsamiającego sposobu lektury, w którym cudzy tekst traktowany jest jako zapis analogicznego doświadczenia, co przekłada się na wiarę w tożsamość ludzkiej kondycji ${ }^{51}$ : „Cytaty z lektur są integralne $\mathrm{z}$ tekstem własnym, notuję bowiem tylko to, co pokrywa się z moimi przemyśleniami, co z nimi współbrzmi lub je dokładniej formułuje" - pisze Kamieńska we wstępie do pierwszego tomu Notatnika ${ }^{52}$, a w innym miejscu dodaje: „Przepisuję to, bo nie mogłabym tego powiedzieć lepiej” ${ }^{33}$. Tak jak u Elzenberga, powtarza się tu Montaigne'owski gest opowiadania o sobie poprzez cytaty, specyficzny brak zaufania do własnego głosu. Jak podkreśla Czermińska, z jednej strony występuje tu ciągłe negowanie możliwości wyrażenia za pomocą języka najgłębszych przeżyć jednostki, a z drugiej traktowanie tradycji jako przestrzeni spotkań i rezerwuaru sposobów wyrażania ${ }^{54}$. Z Elzenbergiem i Brzozowskim podziela też poetka odczytywanie tekstów kultury jako przejawów autobiografizmu, czemu daje wyraz, przywołując cytowany już tutaj fragment Pamiętnika autora Płomieni:

[...] w poezji naprawdę nie ma nic, gdy nie ma biografii [...] Brzozowski powiedział: „Co nie jest biografią, nie jest w ogóle" 55 .

49 Ibidem, s. 296.

${ }^{50}$ Por. M. Czermińska, op. cit., s. 103-104.

${ }^{51}$ Por. ibidem, s. 109.

${ }^{52}$ A. Kamieńska, op. cit., s. 6.

${ }_{53}$ Cyt. [za:] M. Czermińs k a, op. cit., s. 109.

${ }^{54}$ Por. ibidem, s. 113.

55 A. Ka mieńs k a, Autointerpretacja [w:] Na progu słowa, Poznań 1985, s. 10. Cyt. [za:] M. Czermińska,op. cit., s. 110. 
Działanie pisarstwa to nie środki wyrazu, nie styl, nie myśl nawet, ale obcowanie z osobowością autora, rozpoznawanie człowieka (67 II) ${ }^{56}$.

Mamy więc kolejną opowieść o własnym doświadczeniu zapośredniczoną przez teksty cudze, rozwijającą się w dialogu z innymi diarystami (m.in. Elzenberga i Konińskiego).

Czermińska podkreśla, że poetka odmawia swojemu tekstowi charakteru dziennikowego czy pamiętnikowego, bo nie próbuje w nim odtworzyć całości życia, oddaje tylko pewien jego nurt ${ }^{57}$. Mamy tu do czynienia z szeregiem metaforycznych określeń, takich jak: „znaki, sygnały, ślady na pisaku”58, „strzępy”. Bez wątpienia jednak był to tekst niezwykle ważny dla autorki, spełniający funkcje typowe dla zapisów diarystycznych. Dziennik Kamieńskiej jest, podobnie jak zapiski Elzenberga, rodzajem praktyki etycznej, wysiłkiem samokształtowania i samorozumienia:

Myślę o tych zapiskach, że są tylko jednym planem mojego życia, jakbym nie przeżywała nic z tego, co dzieje się na świecie. Ja tu, w tych zapiskach, po prostu jes te m, a raczej usiłuję być, usiłuję i próbuję. A to jest rzecz bardzo trudna. Bodaj zaistnieć. Jak u Norwida: „Lecz bą dź raz przecie!" 60

W innym miejscu cytuje Valéry’ego: „Budując swoje dzieło, zbudowałem sam siebie"61, a niedługo potem notuje w kontekście dzienników Lechonia:

Zapisywanie swoich myśli jest potrzebne i zarazem szkodliwe. Sprzyja egocentryzmowi, narcyzmowi, utrwala to, co winno przemijać. Ale z drugiej strony te zapiski sprzyjają intensywności życia wewnętrznego, które nie wyrażone - przecieka przez palce. Gdyby można było znaleźć lepszą formę dzienników, skromniejszą, utrwalić sam miąższ życia, który wart jest utrwalenia ${ }^{62}$.

Patronem takiego rozumienia własnego tekstu jest dla poety Elzenberg, a jego słowa stanowią swoisty leitmotiv tekstu Notatnika:

Sama naga egzystencja jest bolesna, gdy wyłania się spoza wszystkich wartości utraconych. Znosić sam nagi byt - to dopiero heroizm.

Elzenberg: „Być mężnym wobec bytu”. To właśnie to ${ }^{63}$.

\footnotetext{
${ }^{56}$ Cyt. [za:] M. Czermińska, op. cit., s. 110.

${ }^{57}$ M. Czermińska, op. cit., s. 105.

${ }_{58}$ A. Kamień ska,op. cit., s. 192.

${ }^{59}$ Ibidem, s. 238.

${ }^{60}$ Ibidem, s. 249.

${ }^{61}$ Ibidem, s. 60.

62 Ibidem, s. 61.

${ }^{63}$ Ibidem, s. 296.
} 
Charakterystyczne, że u wszystkich omawianych twórców pojawia się ten sam zespół problemów związanych z przekraczaniem granicy pomiędzy dyskursem poetyckim a filozoficznym. Nie inaczej rzecz się ma z zapiskami Kamieńskiej. W twórczym instrumentarium poetki metafora czy paradoks wydają się narzędziem najzupełniej naturalnym, widać tu jednak dążenie do stosowania ekspresji literackiej w refleksji filozoficznej i teologicznej:

Oczywiście, język jest systemem metafor [...]. Przyzwyczailiśmy się do wielu słów, zapominając, że są one tylko metaforami, choć w swoim czasie były aż metaforami, czyli językowymi odkryciami. Wydawało mi się, że konieczna jest nieustanna odkrywczość językowa także dziś w zakresie wiary. Myśliciele powinni być poetami ${ }^{64}$.

W innym miejscu diarystka akcentuje, że ekspresyjna wartość metafory tkwi w jej zdolności do oddawania procesualności i dynamiki desygnatu ${ }^{65}$, cytuje też wypowiedź Fromma, który podnosi język symboliczny do rangi uniwersalnego języka ludzkości ${ }^{66}$. Istotną rolę odegrała tu, jak się zdaje, Nietzscheańska koncepcja języka filozoficznego:

Fryderyk Nietzsche: Czymś rozpaczliwym jest dla myśliciela uświadomienie sobie, że nielogiczność potrzebna jest ludziom i że powstaje z niej wiele dobrego.

Element nielogiczności tkwi tak silnie w uczuciach, w języku, w sztuce, w religii i w ogóle we wszystkim, co życiu nadaje wartość, że usuwając go wyrządziliśmy niepowetowaną krzywdę tym pięknym rzeczom ${ }^{67}$.

Autorka boryka się też z problematycznością wszelkich systemów myślowych. Tak jak u Elzenberga i Brzozowskiego istotna jest dla niej osobowość twórcy, leżąca u podstaw konstruktów intelektualnych:

Wszelkie nasze konstrukcje myślowe, tzw. światopoglądy, są tym bardziej zawodne, im bardziej szczelne, „konsekwentne”, bo wówczas nie ma w nich miejsca na błąd, na ryzyko. Właściwy system człowieka to jego życie, jego sposób bycia, jego otwartość na innych ludzi, na sprawy ducha, jego życzliwość wobec świata. Światopogląd jest pusty jeśli nie jest osobowością, pełnią człowieka.

U źródeł sprzeciwu wobec logicyzacji i systemowości myślenia leży, charakterystyczne również dla Elzenberga, przeświadczenie o alogicznej strukturze rzeczywistości, nieskończoności jej aspektów i wielorakości możliwych filozoficznych stanowisk:

Wieloznaczność jest pozytywną stroną świata. Złożoność i bogactwo świata pozwala istnieć obok siebie dwom zdaniom sprzecznym ${ }^{68}$.
${ }^{64}$ Ibidem, s. 125.
65 Ibidem, s. 191.
${ }^{66}$ Ibidem, s. 26.
${ }^{67}$ Ibidem, s. 28.
${ }^{68}$ Ibidem, s. 198. 
Notatnik, podobnie jak wszystkie przywoływane dotąd teksty, jest również zapisem doświadczenia religijnego. Po raz kolejny przezwyciężenie aporii na jakie napotyka racjonalna refleksja okazuje się możliwe w rzeczywistości boskiej:

Religia jest przekonaniem, że jest rozum większy, przekraczający nasze rozumy. Nie jest to jednak postawa sprzeczna z rozumem, irracjonalna. Przeciwnie, jest to wiara w rozum większy od rozumu ludzkiego, raczej jakiś nad-racjonalizm ${ }^{69}$.

Człowiek zawsze dąży do zacierania sprzeczności, do przezwyciężania myślą przeciwieństw. Jest w tym może przeczucie jednej zasady, jednej istoty świata. Mamy przeczucie, że jest coś, co określa i obejmuje zarówno to co wielkie, jak i to, co małe; wiedzę i niewiedzę, świadomość i sen, siłę i słabość, naszą nędzę i godność. Intuicja prawdy, która musi być jedna, aby była prawdą ${ }^{70}$.

Rzeczywistość prawdy pojętej jako „całość” jest jednak tylko postulowana, przeczuwana - nie jest realizowalna. W refleksji Kamieńskiej napotykamy marzenie o całości, ale diarystka wydaje się pogodzona z fragmentarycznością, gdy pisze: „Ludzkie jest to, co niedokończone”71.

Dla Kamieńskiej własny dziennik to „strzępy”, „,okruchy”, „drobiny”, „,́lady", które nie są w stanie wyrazić całości doświadczenia, tekst niedokończony, dla którego nawet określenie „dziennik” nie wydaje się adekwatne, materiał do nigdy nie napisanej autobiografii:

Czasami myślę, czy z tych nieudolnych zapisków nie udałoby się ułożyć książki o pewnym nurcie świadomości. Nie zapisuję tutaj wszystkiego, może nawet uchodzi mi to, co najbardziej istotne. Nie zapisuję wydarzeń, wokół których krystalizują się myśli. Ale i w tym jest jakaś prawda. Cokolwiek się wydarza, nie zagarnia mnie całej, jakbym najważniejsze miała już za sobą. Całe życie skierowane do głębi, jak rzeka, która schodzi pod ziemię ${ }^{72}$.

W kontekście samoświadomości gatunkowej autorki Notatnika znacząca jest, być może, enigmatyczna z pozoru wzmianka o teorii dzieła otwartego Umberta Eco: ,«dzieło otwarte» - chcące uczynić z odbiorcy współtwórcę"”73.

Podsumowując, powiedzieć można, że teksty Brzozowskiego, Konińskiego, Elzenberga i Kamieńskiej stanowią na tle tradycji polskiej wspólną linię pisarstwa intymistycznego, w którym autobiografia przeplata się nieustannie z refleksją, język filozoficzny z językiem typowym dla literatury, a wybór formy fragmentarycznej, czy - szerzej - eseistycznej, wynika ze sformułowanego explicite przeświadczenia o ograniczonej naturze ludzkiej wiedzy i charakterze języka.

\footnotetext{
69 Ibidem, s. 200.

70 Ibidem, s. 206.

71 Ibidem, s. 199.

72 Ibidem, s. 182.

73 Ibidem, s. 244.
} 
Katarzyna Kantner

HENRYK ELZENBERG'S PROBLEM OF EXISTENCE

AND THE POLISH MODERNIST TRADITION OF THE PRIVATE DIARY

(STANISŁAW BRZOZOWSKI, KAROL LUDWIK KONIŃSKI, AND ANNA KAMIEŃSKA)

\section{Summary}

This article tries to position Henryk Elzenberg's Problem of Existence within the tradition of Polish modernist private diary writing. Elzenberg's diary and occasional writings is in many ways exceptional and yet it has many parallels and links with the autobiographical works of Stanisław Brzozowski, Karol Ludwik Koniński and Anna Kamieńska. It is even possible to claim that all those texts constitute a distinct modernist subgenre, defined by its form and tone used to address issues ranging from religion and rationality to the possibility of constructing a new system of thought or finding a vocabulary capable of expressing its philosophical argument. 